\title{
Indoor Air Exposure to Multiple Agricultural Pesticides Potentially Posing the Highest Risk to Young Children
}

\author{
Sithembiso Sifiso Msibi ${ }^{1,2}$, Chung-Yu Chen ${ }^{3}$, Cheng-Ping Chang ${ }^{3}$, \\ Chiou-Jong Chen ${ }^{3}$, Su-Yin Chiang ${ }^{* *}$, Kuen-Yuh Wu ${ }^{1,5^{*}}$
}

${ }^{1}$ Institute of Environmental and Occupational Health Sciences, College of Public Health, National Taiwan University, Taipei 10055, Taiwan

${ }^{2}$ Department of Biological Sciences, Faculty of Science and Engineering, University of Eswatini, Kwaluseni, Eswatini

${ }^{3}$ Department of Occupational Safety and Health, College of Health Sciences, Chang Jung

Christian University, Tainan 71101, Taiwan

${ }^{4}$ School of Chinese Medicine, College of Chinese Medicine, China Medical University, Taichung 40402, Taiwan

${ }^{5}$ Institute of Food Safety and Health, College of Public Health, National Taiwan University,

Taipei 10055, Taiwan

\section{ABSTRACT}

Pesticides are extensively used to improve crop yield and quality in many African countries where agricultural production is a critical economic activity, including Eswatini (formerly Swaziland) in southern Africa. However, the potential health effects of indoor exposure to agricultural pesticides are deeply concerning, and children are particularly vulnerable. This case study assessed such exposure and its risks by sampling and analyzing the air inside the homes of 15 pesticide applicators and 12 non-applicators in Swazi communities surrounded by nearby $(\sim 200 \mathrm{~m})$ sugarcane fields on pesticide spraying days. Applying liquid chromatography with tandem mass spectrometry (LC-MS/MS) to the samples revealed mean ametryn, atrazine, pendimethalin and 2,4-dichlorophenoxyacetic acid (2,4-D) concentrations of $0.75,0.32,0.57$ and $0.004 \mu \mathrm{g} \mathrm{m}^{-3}$, respectively, in the applicator households and corresponding values of $0.19,0.03,0.04$ and $0.003 \mu \mathrm{g} \mathrm{m}^{-3}$, respectively, in the non-applicator households. Notably, the non-applicator households exhibited pesticide concentrations far exceeding previously published data. Furthermore, we measured significantly higher levels of ametryn and pendimethalin inside the homes of the applicators than those of the non-applicators. Daily inhalation exposure to agricultural pesticides resulted in cumulative hazard index values above 1.0 at the $95^{\text {th }}$ percentile for children 3 years of age and younger in the applicator households. Thus, the take-home pathway, spray drift and household-to-field distance all play crucial roles in determining the pesticide exposure and health risks indoors. Owing to the dominance of the first factor, we advise applicators to shower and change into clean clothes before returning home to their families. This safety measure is essential for the many families living near agricultural land throughout Africa.

Taiwan Association for Aerosol Research

ISSN: $1680-8584$ print

ISSN: 2071-1409 online

(c) Copyright: The Author(s).

This is an open access article distributed under the terms of the Creative Commons Attribution License (CC BY 4.0), which permits unrestricted use, distribution, and reproduction in any medium, provided the original author and source are cited.

Keywords: Pesticides, Indoor air, Inhalation exposure, Health risk, Eswatini

\section{INTRODUCTION}

Agricultural production is a very important economic activity in African countries, where pesticides are widely used to maintain high crop yields and quality, improve agricultural productivity and farmers' incomes. However, the application of pesticides potentially leads to indoor exposure amongst people living in agricultural communities, due to spray drift and the take-home pathway 
(Weppner et al., 2006; Chang et al., 2014; Gibbs et al., 2017; Taylor et al., 2020). Residential indoor exposure to pesticides has been associated with deleterious health effects, particularly among women and children, including an increase in risk for breast cancer, menstrual cycle disturbances, adverse birth outcomes, thyroid disorders, leukemia, non-Hodgkin lymphoma, asthma, childhood hematopoietic malignancies, autism spectrum disorders and neurodevelopmental delays following prenatal and early childhood exposure to pesticides (Alavanja et al., 1999; Ma et al., 2002; Windham et al., 2002; Farr et al., 2004; Menegaux et al., 2006; Rudant et al., 2007; El-Zaemey et al., 2013; Shelton et al., 2014; Campos and Freire, 2016; Larsen et al., 2017; Mostafalou and Abdollahi, 2017; Cherry et al., 2018; Hyland et al., 2018; Van Maele-Fabry et al., 2019; Dereumeaux et al., 2020; Chetty-Mhlanga et al., 2021). Thus, it is critically important to assess household exposures to pesticides and corresponding health risks for residents living in and around agricultural communities. Families in surrounding residential areas may also potentially be exposed to agricultural pesticides, which can drift from the intended application sites on spraying days.

Several studies have found that close proximity of households to agricultural land is associated with high levels of biological markers of pesticides (Wu et al., 2013; Chevrier et al., 2014; SuarezLopez et al., 2018) and high pesticide concentrations in households (Lu et al., 2000; Gibbs et al., 2017). Conversely, other research has not found this positive relationship between household proximity and pesticide levels (Curwin et al., 2005; Ward et al., 2006). Evidence has also shown that pesticides sprayed on fields can drift from the spraying area by up to $400 \mathrm{~m}$ (Fenske et al., 2002; Koch et al., 2002; Siebers et al., 2003; Quandt et al., 2004; Carlsen et al., 2006; Wolters et al., 2008) and $750 \mathrm{~m}$ (Ward et al., 2006). Moreover, living with a farmworker has been associated with an increase in pesticide concentrations in the household (Gibbs et al., 2017; Bennett et al., 2019; López-Gálvez et al., 2019; Dereumeaux et al., 2020). Research has shown that farmworkers transfer pesticide residues home on their clothes, skin and footwear, and thus expose their family members (Bradman et al., 2011; Coronado et al., 2011b). The presence of agricultural pesticides indoors potentially exposes population groups who are highly sensitive to pesticides, such as children and the elderly (NRI, 1993; Ginsberg et al., 2004). Children are an extremely vulnerable group, because of their greater body weight to body surface area and respiratory, metabolic and circulatory rates compared with adult values (Berglund et al., 1992; Grandjean and Landrigan, 2006; Landrigan and Goldman, 2011; Thompson et al., 2014), enabling pesticide residues to accumulate and distribute substantially faster throughout children's bodies compared with adult bodies (Thompson et al., 2014). The impact of household pesticide exposure in children is therefore of enormous concern.

Household exposure to agricultural pesticides has rarely been studied in African countries and may exhibit different patterns of exposure and levels of susceptibility compared to those in other parts of the world (El-Gamal et al., 2017; Joubert et al., 2019), due to the fact that many farmworkers reside near farm fields. Since $90 \%$ of global malaria cases occur in the African region (WHO, 2016), most studies conducted in African countries have focused on the use of indoor residual spraying of dichlorodiphenyltrichloroethane (DDT) and its breakdown product dichlorodiphenyltrichloroethylene (DDE), since DDT is used to control malaria vectors in African countries (Barnhoorn et al., 2009; Van Dyk et al., 2010; Naudé and Rohwer, 2012; Hlongwana et al., 2013; Gaspar et al., 2015; Coker et al., 2018; Murray et al., 2018). To assess agricultural pesticide exposure and associated health risks among farmers and residents in agricultural communities, some studies have relied heavily on questionnaires alone (Oesterlund et al., 2014; da Silva et al., 2016; Manyilizu et al., 2016; Sankoh et al., 2016; Debela et al., 2019), while other African studies have only investigated the presence and concentrations of pesticides in ambient air (Shunthirasingham et al., 2010a, b; Moussaoui et al., 2012; Dalvie et al., 2014; Arinaitwe et al., 2016; Fuhrimann et al., 2020). To the best of our knowledge, this case study is the first to be performed in Africa that has assessed the potential health risks resulting from inhalation exposure to indoor air concentrations of multiple agricultural pesticides sprayed on nearby fields. We collected indoor air samples from applicator and nonapplicator households in Eswatini (formerly Swaziland) in southern Africa residing in close proximity $(\sim 200 \mathrm{~m})$ to sugarcane fields and analyzed all of the samples for evidence of the most commonly used pesticides in sugarcane production in Eswatini: ametryn, atrazine, pendimethalin and 2,4dichlorophenoxyacetic acid (2,4-D). We compared airborne levels of these pesticides between applicator and non-applicator households and assessed health risks relating to indoor inhalation exposure of these pesticides. This study sought to highlight the potential impacts of agricultural 
pesticides to families and especially children living in agricultural communities in African countries, where many farmworker families may be located very close to farmlands.

\section{MATERIALS AND METHODS}

\subsection{Sampling Area}

Sampling was conducted in an agricultural community in Vuvulane, in the north-eastern part of Eswatini. This community resides in a commercial sugarcane farm, situated at $26.07^{\circ} \mathrm{S}$ and $31.87^{\circ} \mathrm{E}$ in the Lowveld region of the country. The farm grows sugarcane throughout the year and relies on irrigation systems. For the purpose of this study, households in the community were categorized as either applicator or non-applicator households. Applicator households were defined as households having one or more pesticide applicator(s) living in the household. Non-applicator households had no applicator(s) living in the household and members of these households were non-farm workers, whose occupations included teaching in the local community school and factory work. The applicator households belonged to the participants of our previous investigation that assessed the applicators' pesticide inhalation exposures (Msibi et al., 2021). Some of the participants in that study kindly invited us to their homes after completing spraying activities for the day. Neighboring non-applicator households were used as controls. Fig. 1 presents a map of the sampling area. At each household visit, we briefed the members about our sampling procedure and study, in order to allay any concerns or suspicions about the motives of our research. Informed consent was obtained from all households in this study, which received ethical approval from the National Health Research Review Board (NHRRB) in Eswatini.

\subsection{Indoor Air Sampling}

Indoor air sampling was conducted in 15 applicator and 12 non-applicator households in the afternoons, following the application of pesticides in the fields. To assess indoor pesticide levels, air samples were collected from each residence over 2 consecutive days during the summertime pesticide spraying season in December 2018. The United States Environmental Protection Agency (U.S. EPA) Compendium of Methods for the Determination of Toxic Organic Compounds in Ambient Air: Second Edition was used as a guideline (U.S. EPA, 1999). An air sampling apparatus was set up each afternoon to collect air samples in the living rooms of applicators' and nonapplicators' homes. In each case, the sampling pump (AirChek 52, Part No. 224-52; SKC, Inc., USA) was mounted on a stand and positioned at a breathing zone height of $\sim 1.4 \mathrm{~m}$. The flow rate was set at $1 \mathrm{~L} \mathrm{~min}-1$ and XAD-2 OVS tubes (Cat. No. 226-58) were used to capture pesticide residues in the air. The set-up was the same in both sets of households. All applicator and non-applicator households were located within $200 \mathrm{~m}$ of the sugarcane fields (Fig. 1).

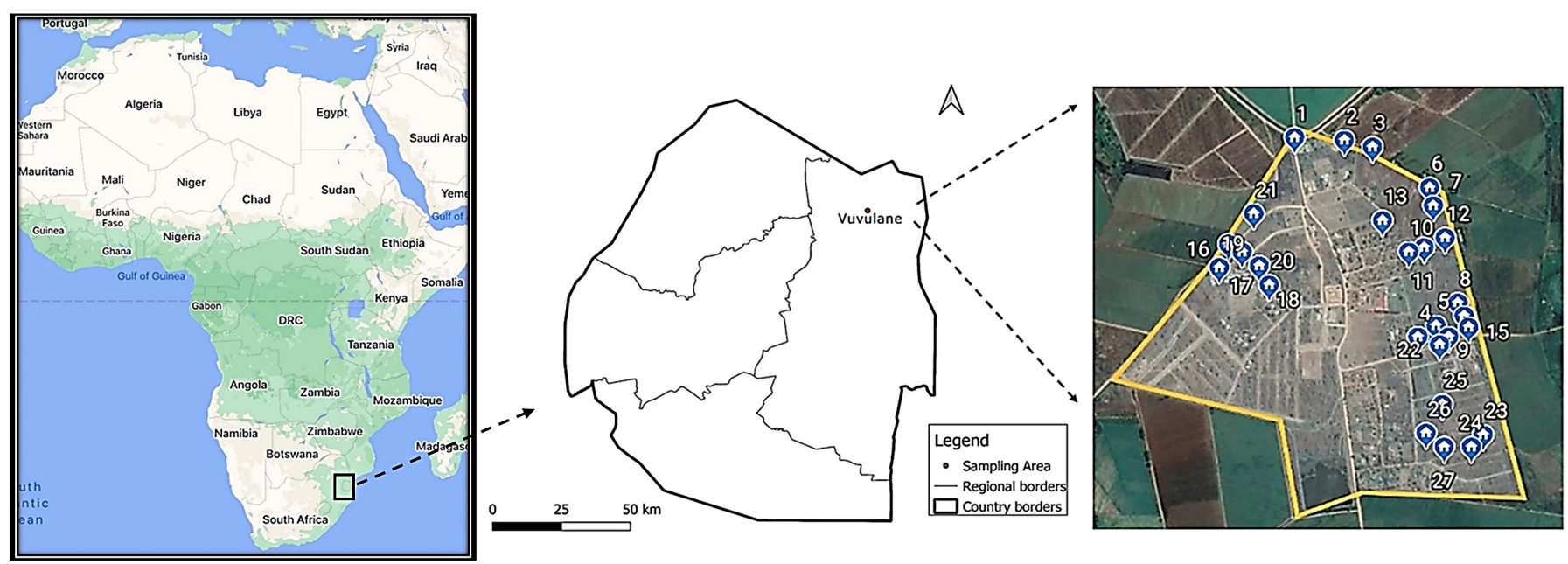

Fig. 1. A map of Africa showing the location of Eswatini (left), a map of Eswatini (center) and an insert of the sampling area, showing the households surrounded by sugarcane fields (right). 
Air temperatures and relative humidity $(\mathrm{RH})$ values were monitored at the start and end of sample collection (Table S1) using a Lutron temperature/humidity monitor (Taipei, Taiwan). We calibrated the sampling pumps on site before and after sample collection, using a Gilibrator- 2 Calibrator (Sensidyne, Florida, USA). Variation in the pump flow before and after sampling had to be less than $5 \%$. After sampling, all the relevant data were recorded and sample tubes were securely covered with caps on both ends and sealed in labeled polyethylene zipper bags. Field blanks were also prepared in the living room by using clean, unused cartridges. They were handled, labeled and stored the same way as the collected air samples, except that no air was drawn through them. All samples were stored in a cooler box with ice and transported to the University of Eswatini in Kwaluseni, where they were stored at $-10^{\circ} \mathrm{C}$ in a laboratory, before shipment in dry ice to Taiwan, where they were stored in $\mathrm{a}-20^{\circ} \mathrm{C}$ freezer until analysis.

\subsection{Pesticide Analysis and Quality Control}

LC grade methanol and acetonitrile were purchased from Merck (Darmstadt, Germany). SigmaAldrich provided analytical grade standards of ametryn (CAS No. 834-12-8), atrazine (Cas No. 1912-249), pendimethalin (CAS No. 40487-42-1) and 2,4-D (CAS No. 94-75-7), with individual purities exceeding $98 \%$ for all chemicals. Sigma-Aldrich also supplied formic acid and ammonium acetate. Cambridge Isotope Laboratories, Inc., supplied the internal standard, atrazine (ethylamine-d5) $100 \mu \mathrm{g} \mathrm{mL} \mathrm{m}^{-1}$ in Nonane. The analyte stock solution ( $1 \mathrm{mg} \mathrm{mL}^{-1}$ ) and internal standard (1 $\mu \mathrm{g} \mathrm{mL}^{-1}$ ) were both prepared in acetonitrile, then stored for later dilutions and mixtures in glass vials at $-10^{\circ} \mathrm{C}$.

Samples were analyzed in June 2019, in Tainan, Taiwan. Liquid chromatography with tandem mass spectrometry (LC-MS/MS) analysis was performed using a Shimadzu UHPLC LC-30A system with an LCMS-8045 triple quadrupole mass spectrometer equipped with a heated electrospray ionization (ESI) probe (Shimadzu Corp., Japan). The instrument was injected with $5 \mu \mathrm{L}$ of the sample for analysis. Chromatographic separation was achieved using a $100 \mathrm{~mm} \times 2.1 \mathrm{~mm}$ reverse-phase $2.6 \mu \mathrm{m}$ SpeedCore C18 column (Fortis Technologies, UK) set at $35^{\circ} \mathrm{C}$. A gradient mobile-phase system consisting of Mobiles $A$ and $B$ was used, which worked at a flow rate of $300 \mu \mathrm{L} \mathrm{min}{ }^{-1}$. Mobile A contained $0.4 \mathrm{~g}$ ammonium acetate and $1 \mathrm{~mL}$ of formic acid in 1,000 $\mathrm{mL}$ of ultrapure water, while Mobile B contained $0.4 \mathrm{~g}$ ammonium acetate in 1,000 $\mathrm{mL}$ of methanol. Due to the differing ESI polarities in the analytes, the mass spectrometer was operated using the multiple reaction monitoring (MRM) mode, incorporating both positive and negative ESI modes, as per our previous paper (Msibi et al., 2021).

For sample extraction, $1.2 \mathrm{~mL}$ of methanol was added to the samples. The analytes were then extracted from the samples using an ultrasound bath (Delta Ultrasonic Cleaner; Power Stop Co., Ltd., Bangkok, Thailand) using an ultrasound frequency of $40 \mathrm{kHz}$ and $600 \mathrm{~W}$ of power for $30 \mathrm{~min}$. The extracts were removed from the vial using a syringe and a needle, filtered through a nylon filter of $0.22 \mu \mathrm{m}$ (13 mm diameter) into $1.5 \mathrm{~mL}$ vials, capped and labeled. Samples were then run through the LC-MS/MS instrument. The instrument was calibrated for each target compound,

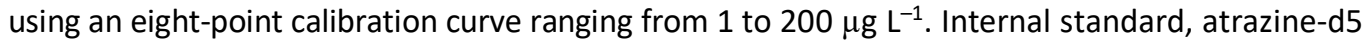
( $5 \mu \mathrm{L}$ of $1 \mu \mathrm{g} \mathrm{mL} \mathrm{m}^{-1}$ ), was added to all air samples to quantify the concentrations of the target compounds. Quality assurance/quality control (QA/QC) samples were incorporated during sampling to enhance sample integrity, increase confidence in the analytical data and to check for any contamination. For quality control during instrument analysis, we ran a calibration recovery standard after every 10 samples. Recovery was determined in this study for each target compound. XAD-2 OVS resin was spiked with three different concentrations of the standard: 5, 50 and $200 \mu \mathrm{g} \mathrm{L}^{-1}$. The spiked resin was left at $4^{\circ} \mathrm{C}$ for $24 \mathrm{~h}$. Samples were extracted using the sample treatment procedure outlined in this study. The percentage recovery was calculated by comparing instrument analysis results with the concentration spiked into the sample (Ho et al., 2012; Hamsan et al., 2017).

Calibration curves were obtained for all analytes to determine pesticide amounts in indoor air. Eight-point calibration curves were derived from 1-200 $\mu \mathrm{g} \mathrm{L}^{-1}$, with regression coefficients $\left(R^{2}\right)$ ranging from 0.9965 to 0.9984 . Recovery efficiencies for the spiked XAD-2 OVS resin samples were $100.4 \%$ for ametryn, $118.8 \%$ for atrazine, $83.8 \%$ for pendimethalin and $76.6 \%$ for $2,4-D$ (Table S2). 


\subsection{Pesticide Concentrations in Households}

We used the internal standard to quantify the analyte concentration of indoor air samples. We manually integrated the peak areas of analytes in each sample using the internal standard quantification method. After peak integration, analyte masses were converted to concentrations $\left(\mu \mathrm{g} \mathrm{m}^{-3}\right)$, using stepwise calculations. We initially divided the detected instrument results for each target compound by the recovery for the respective compounds. The results (in $\mu \mathrm{g} \mathrm{L}^{-1}$ ) were then multiplied with $1.2 \mathrm{~mL}$ (volume used in extraction) and divided by the volume of sampled air, which was calculated from the sample flow rate and duration. The airborne concentration was calculated using the following equation (HSE, 2015):

$$
C_{\text {air }}\left(\mu \mathrm{g} \mathrm{m}^{-3}\right)=\frac{M \times V}{V_{\text {air }}}
$$

In this equation, $\mathrm{C}_{\text {air }}$ is the concentration of pesticides in air, $\mathrm{M}$ is the total mass of analyte in the sample $\left(\mu \mathrm{g} \mathrm{L}^{-1}\right), \mathrm{V}$ is the final volume of the extract $(0.0012 \mathrm{~L})$ and $V_{\text {air }}$ is the volume of air sampled $\left(\mathrm{m}^{3}\right)$. $V_{\text {air }}$ was calculated using this equation:

$V_{\text {air }}\left(\mathrm{m}^{3}\right)=\frac{F \times T}{1,000}$

In this equation, $\mathrm{F}$ is the flow rate $\left(\mathrm{L} \mathrm{min}^{-1}\right), \mathrm{T}$ is the sampling time $(\mathrm{min})$ and 1,000 is used to convert from $L$ to $\mathrm{m}^{3}$. For calculating averages, we assigned a proxy value of half of the limit of detection (LOD), in cases where sample concentrations were below the LOD (<LOD).

\subsection{Probabilistic Assessment of Indoor Exposure and Health Risk}

Indoor household exposures to pesticides can occur through inhalation, dermal absorption and ingestion pathways (NRI, 2000; Özkara et al., 2016). In this study, the health risk from chronic inhalation exposure of pesticide residues in households was assessed for different age groups ( $<0.5$ years, $0.5-0.9$ years, $1-3$ years, $4-12$ years, $13-18$ years, $19-65$ years, $>65$ years). Based on the cancer classification of pesticides by the U.S. EPA, all our target compounds were noncarcinogenic (U.S. EPA, 2018) (Table S3). We therefore applied the following equation to calculate the health risk (U.S. EPA, 1997):

$$
A D D_{i}=\frac{C_{i} \times \operatorname{Inh} R \times E F \times E D}{B W \times A T}
$$

where $\mathrm{i}=1-4$, representing ametryn, atrazine, pendimethalin and 2,4-D; $A D D_{i}$ is the average daily dose $\left(\mathrm{mg} \mathrm{kg}^{-1}\right.$ day $\left.^{-1}\right)$ for i pesticide; $C_{i}$ is the concentration of i pesticide in the air $\left(\mathrm{mg} \mathrm{m}^{-3}\right)$; InhR is the daily inhalation rate for each age group $\left(\mathrm{m}^{3}\right.$ day $\left.^{-1}\right)$ (U.S. EPA, 2011; EFSA, 2014); EF is the exposure frequency (260 days $\mathrm{y}^{-1}$ ); and ED is the exposure duration (years). BW is the body weight $(\mathrm{kg})$ and AT is the averaging time (days). The long-term non-carcinogenic health risk, expressed as the hazard quotient (HQ), was calculated by comparing the inhalation exposure (ADD) with the reference dose (RfD) of each target compound, as follows (U.S. EPA, 1998):

$$
H Q_{i}=\frac{A D D_{i}}{R f D_{i}}
$$

The level of concern for the $\mathrm{HQ}_{\mathrm{i}}$ value was set as 1 , so an $\mathrm{HQ}_{i}$ value $>1$ indicates a potential risk. The $R f D_{i}$ was chosen as the health-based reference value (HBRV) for i pesticide and was cited from the USEPA databases. Cumulative exposures to pesticides were estimated using a hazard index (HI) using the following formula (U.S. EPA, 1998):

$$
H I=\sum_{i=1}^{4} H Q_{i}
$$


The $\mathrm{HI}$ level of concern was set at 1.0; thus, an $\mathrm{HI}$ value $>1$ indicates that a potential risk may be present.

For probabilistic assessment, we used Microsoft Excel ${ }^{\mathrm{TM}} 2016$ and Oracle ${ }^{\complement}$ Crystal Ball Release 11.1.2.4.00 software (Oracle Corp., USA) to run 50,000 Monte Carlo (MC) simulations. Prior to estimation of the $A D D_{i}$, we used Crystal Ball software to determine the distribution (lognormal) of the concentrations of each pesticide. The inhalation rates and body weight values were also assumed to be lognormally distributed (Table S4) and the correlation coefficient between inhalation rate and body weight was set at 0.5 (U.S. EPA, 2011). Inhalation rate values for the different age groups were obtained from the U.S. EPA Exposure Factors Handbook: 2011 Edition (U.S. EPA, 2011). Body weights for adults were adopted from the Eswatini Government's Disease Risk Factor Surveillance Report (DRFSR) (Eswatini Government, 2014) and those for other age groups were adopted from the USEPA Exposure Factors Handbook. We estimated the EF to be 260 days $\mathrm{y}^{-1}$ divided by 365 days $\mathrm{y}^{-1}=0.712$. Since our measurements were performed on application days, we used the estimated annual number of application days (260 days) as the exposure frequency. This is based on information provided by the applicators. Our study population was separated into age groups, with different body weights and inhalation rates; therefore, we calculated annual risks. The ED was set at 1 year and the AT (days) was calculated as the ED multiplied by 365 days $\mathrm{y}^{-1}$. Thus, ED and AT are essentially simplified to 1 . After calculating the $A D D_{i}$ values for all age groups, we divided them by the $R f D_{i}$ values for the target compounds to obtain the $\mathrm{HQ}_{\mathrm{i}}$ values. The $\mathrm{RfD}_{\mathrm{i}}$ values used were 0.009 for ametryn, 0.035 for atrazine, 0.04 for pendimethalin and $0.01 \mathrm{mg} \mathrm{kg}^{-1} \mathrm{day}^{-1}$ for 2,4-D (U.S. EPA, 2020) (Table S3).

\subsection{Statistical Analysis}

Exposure data were handled using Microsoft Excel, to determine descriptive statistics such as frequencies, means and ranges. Some graphs were plotted using R Studio. To determine any significant differences, we compared the concentrations of each pesticide in applicator and nonapplicator households using a two-sample $t$-test, assuming unequal variances $(\alpha=0.05)$. Betweengroup differences were treated as significant when $p$-values were $<0.05$.

\section{RESULTS AND DISCUSSION}

\subsection{Airborne Pesticide Levels in Households}

Indoor air samples were collected from 27 households, 15 of which were applicator households and 12 were non-applicator households. Analyte samples in the gas phase were collected in the living rooms of the households, with an average sampling time of $8.99 \mathrm{~h}(\mathrm{SD}=2.45)$. Fig. S1 shows a chromatogram of the target compounds from an applicator's household. Fig. 2 shows the concentrations from applicator and non-applicator households. All target compounds except for 2,4-D were detected in all of the samples; detection frequencies for $2,4-D$ were $33.3 \%$ in the applicator and non-applicator households (Table 1). For all target compounds, pesticide concentrations were higher in samples collected from applicators' households compared with those from non-applicator households (Fig. 2); ametryn was the most commonly detected compound in both sets of households, with mean concentrations of $0.75 \pm 1.09 \mu \mathrm{g} \mathrm{m}^{-3}$ and 0.19 $\pm 0.28 \mu \mathrm{g} \mathrm{m}^{-3}$, respectively. This is consistent with the results of our previous paper (Msibi et al., 2021), which showed that in comparison with the other target compounds, the amount of ametryn used was the highest. The general trend in application rate $\left(\mathrm{kg} \mathrm{ha}^{-1}\right)$ of the four herbicides was: ametryn $>$ pendimethalin $>$ atrazine $>2,4-D$. Our analysis showed that differences were only statistically significant for ametryn $(p=0.038)$ and pendimethalin $(p=0.03)$; the difference between the concentrations from the two sets of households was not statistically significant for atrazine $(p=0.06)$ (see Table 1$)$. Concentrations of pesticides detected in each household are given in Table $\mathrm{S} 5$.

\subsubsection{Spray drift}

In non-applicator households, our data reveal mean indoor air concentrations of $0.19 \pm 0.28$ $\mu \mathrm{g} \mathrm{m} \mathrm{m}^{-3}$ for ametryn, $0.03 \pm 0.03 \mu \mathrm{g} \mathrm{m}^{-3}$ for atrazine, $0.04 \pm 0.04 \mu \mathrm{g} \mathrm{m}^{-3}$ for pendimethalin and $0.003 \pm 0.001 \mu \mathrm{g} \mathrm{m}^{-3}$ for 2,4-D (Table 1$)$. Households in this study were in close proximity $(\sim 200 \mathrm{~m})$ 


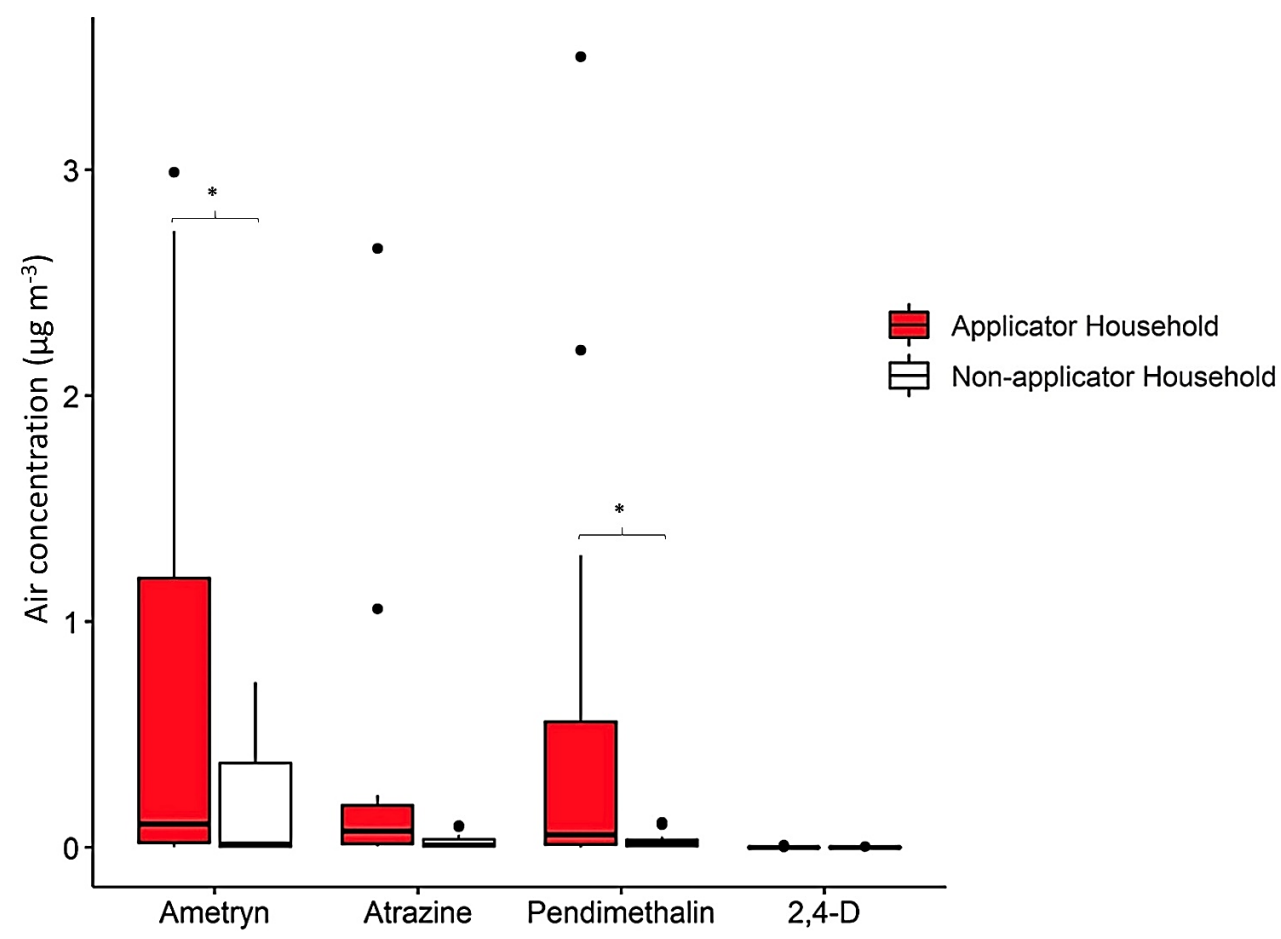

Fig. 2. Box plots showing pesticide concentrations in indoor air samples collected from applicator and non-applicator households. * Statistically significant $(p<0.05)$.

Table 1. Mean concentrations of target compounds from applicator and non-applicator households $\left(\mu \mathrm{g} \mathrm{m} \mathrm{m}^{-3}\right)$.

\begin{tabular}{|c|c|c|c|c|c|c|c|}
\hline \multirow{2}{*}{ Target compounds } & \multicolumn{3}{|c|}{ Applicator households $(n=15)$} & \multicolumn{3}{|c|}{ Non-applicator households $(n=12)$} & \multirow{2}{*}{$p$-value } \\
\hline & Frequency of detection & Mean & SD & Frequency of detection & Mean & SD & \\
\hline Ametryn & 15 & 0.75 & 1.09 & 12 & 0.19 & 0.28 & $0.038^{*}$ \\
\hline Atrazine & 15 & 0.32 & 0.70 & 12 & 0.03 & 0.03 & 0.062 \\
\hline Pendimethalin & 15 & 0.57 & 1.03 & 12 & 0.04 & 0.04 & $0.030 *$ \\
\hline 2,4-D & 5 & $0.004^{b}$ & 0.004 & 4 & $0.003^{b}$ & 0.001 & - \\
\hline
\end{tabular}

${ }^{a}$-values were calculated using a two-sample $t$-test.

${ }^{b}$ For calculating averages, the proxy value (half of LOD) was assigned for samples $<$ LOD.

$* p<0.05$.

to and surrounded by sugarcane fields and our results suggest that the presence of pesticides in non-applicator households could be due to spray drift from sprayed nearby fields. Factors influencing spray drift and distance traveled include the application method and equipment, weather conditions, the amount of pesticide used, the distance from the source to the sampling site and topography (Weppner et al., 2006; Coronado et al., 2011a). Studies have shown that concentration of pesticide decreases with increasing distance from the spraying area (inverse correlation) (Simcox et al., 1995; Kawahara et al., 2005; Coronado et al., 2011a; Brouwer et al., 2018). Our results are consistent with previous investigations demonstrating that pesticide drift can reach households within $400 \mathrm{~m}$ from the spraying area (Fenske et al., 2002; Koch et al., 2002; Siebers et al., 2003; Quandt et al., 2004; Carlsen et al., 2006) and another study that detected pesticide residues $750 \mathrm{~m}$ from the spraying area (Ward et al., 2006).

Curwin et al. (2005) reported that atrazine and 2,4-D were below detectable levels in all air samples collected from farm and non-farm homes, in lowa, USA. This could be possibly because some homes in that study were located at around $800 \mathrm{~m}$ from the sprayed fields and thus the concentrations were very low at the sampling sites (homes). Moreover, the air samples were collected 7 days (first visit) and 30 days (second visit) after the application of pesticides in the field. In contrast, in our study, households were much closer to the sprayed fields ( 200 m) and we collected indoor air samples on the day of pesticide application. It would therefore be 
reasonable to expect that our data would show higher levels of pesticides. In another study, mean pesticide concentrations ranged from $<$ LOD to $0.023 \mu \mathrm{g} \mathrm{m}^{-3}$ in homes of non-applicators in an agricultural community in Japan (Kawahara et al., 2005). These are much lower than our results, as our mean concentration for all four target compounds from non-applicator households ranged from $<$ LOD to $0.19 \mu \mathrm{g} \mathrm{m}^{-3}$ (Table 2). The lower pesticide levels in the Japanese investigation can be explained by the fact that some of the homes were situated more than $400 \mathrm{~m}$ from the sprayed field. A USA-based study involving a farm housing community in central Washington investigated the role of off-target pesticide drift as a pathway for human exposure in nearby communities (Weppner et al., 2006). The households in that study were closer to the nearest sprayed fields than the households in our study, which is reflected by the much higher reported pesticide levels in outdoor air from the non-applicator households in the USA study (median: 0.48 $\mu \mathrm{g} \mathrm{m}^{-3}$ ) than our indoor air results ( $<\mathrm{LOD}-0.19 \mu \mathrm{g} \mathrm{m}^{-3}$ ). Moreover, households in the USA study were surrounded by potato, corn and wheat fields and were within 15-200 $\mathrm{m}$ of the nearest treated field, while the highest concentration $\left(0.98 \mu \mathrm{g} \mathrm{m}^{-3}\right)$ was recorded from a household located within 10-20 $\mathrm{m}$ from the nearest field. Study evidence also shows that the likelihood of spray drift increases during the summer, as a result of spray volatilization due to high temperatures (Kawahara et al., 2005; Gibbs et al., 2017). Sprayed pesticides evaporate at high temperatures during summer months and partially attach to suspended air particles, then diffuse and transfer through air to reach off-target sites. Our study samples were collected during summer, when household windows and doors were open during the day because of high temperatures (mean afternoon temperatures: $28.6^{\circ} \mathrm{C}$ and $31.1^{\circ} \mathrm{C}$ ) while pesticide spraying and sample collections were conducted (Table S1), so pesticides sprayed in the fields potentially penetrated indoors. Wind conditions were calm during the pesticide applications, although we did not measure wind speed due to lack of instrumentation, as detailed in our previous paper (Msibi et al., 2021); elevated temperatures were a contributing factor to household exposure through spray drift.

Table 2 presents a comparison of published data from studies performed in countries outside Africa that have analyzed pesticide concentrations in indoor and outdoor air in agricultural communities. Compared with the published data, the mean concentrations from our study are higher than those in studies from Japan (Kawahara et al., 2005) and the USA (Whitmore et al., 1994; Lu et al., 2004; Curwin et al., 2005; Gibbs et al., 2017). This is mainly due to the fact that in comparison with most of the studies in Table 2, our sampling sites (households) were much closer to the sprayed fields, as we noted earlier. However, one study from the USA reported higher indoor air concentrations in non-applicator households. Whitmore et al. (1994) investigated indoor air

Table 2. A comparison of indoor pesticide concentrations in this study with those in published data from other countries.

\begin{tabular}{|c|c|c|c|c|c|c|}
\hline \multirow[b]{2}{*}{ Country } & \multirow{2}{*}{$\begin{array}{l}\text { Target } \\
\text { compound }\end{array}$} & \multicolumn{2}{|c|}{ Mean concentrations $\left(\mu \mathrm{g} \mathrm{m}^{-3}\right)$} & \multirow{2}{*}{$\begin{array}{l}\text { Sampling } \\
\text { location }\end{array}$} & \multirow[b]{2}{*}{ Sample size } & \multirow[b]{2}{*}{ References } \\
\hline & & $\begin{array}{l}\text { Applicator } \\
\text { household }\end{array}$ & $\begin{array}{l}\text { Non-applicator } \\
\text { household }\end{array}$ & & & \\
\hline Eswatini & 4 pesticides & $<$ LOD-0.75 & $<$ LOD-0.19 & Indoor air & 27 households & This study \\
\hline Japan & 7 pesticides & - & $<$ LOD-0.023 & $\begin{array}{l}\text { Indoor and } \\
\text { outdoor air }\end{array}$ & 55 households & $\begin{array}{l}\text { Kawahara et al. } \\
\text { (2005) }\end{array}$ \\
\hline lowa, USA & 6 pesticides & - & $<$ LOD-0.05 & Indoor air & 20 homes & $\begin{array}{l}\text { Curwin et al. } \\
\qquad(2005)\end{array}$ \\
\hline Washington, USA & $\begin{array}{l}2 \text { pesticides and } \\
\text { their oxygen } \\
\text { analogs }\end{array}$ & $\begin{array}{l}3 \times 10^{-5}-5.4 \times \\
10^{-3}\end{array}$ & $<$ LOD-2 $\times 10^{-4}$ & $\begin{array}{l}\text { Indoor and } \\
\text { outdoor air }\end{array}$ & 13 households & $\begin{array}{l}\text { Gibbs et al. } \\
\text { (2017) }\end{array}$ \\
\hline Washington, USA & Methamidophos & - & $0.05-0.48$ & $\begin{array}{l}\text { Indoor and } \\
\text { outdoor air }\end{array}$ & 6 households & $\begin{array}{l}\text { Weppner et al. } \\
\text { (2006) }\end{array}$ \\
\hline $\begin{array}{l}\text { Florida, USA; } \\
\text { Massachusetts, USA }\end{array}$ & 22 pesticides & - & $<$ LOD-0.529 & Indoor air & - & $\begin{array}{l}\text { Whitmore et al. } \\
\text { (1994) }\end{array}$ \\
\hline Washington, USA & 5 pesticides & $\begin{array}{c}2 \times 10^{-3}-4 \times \\
10^{-3}\end{array}$ & - & Indoor air & 6 homes & Lu et al. (2004) \\
\hline
\end{tabular}


pesticide levels in non-applicator households at two study sites in the USA. Their indoor air concentrations range from $<$ LOD to $0.529 \mu \mathrm{g} \mathrm{m} \mathrm{m}^{-3}$ and are higher than our findings from nonapplicator households, although it is worth noting that the households in that USA study also reported the use of pesticides on indoor plants and the use of insecticides to control household pests (Whitmore et al., 1994). Gibbs et al. (2017) investigated indoor and outdoor air concentrations of chlorpyrifos and azinphos-methyl, with their analogs, in households in an agricultural region of central Washington, USA. They found higher indoor air levels of the target pesticides in farmworker households with close proximity to tree fruit fields ( $\leq 250 \mathrm{~m}$ from the nearest tree fruit field) compared with non-proximal households (>250 $\mathrm{m}$ from the nearest tree fruit field). In that study, the reported indoor air concentrations for proximal households ranged from $3 \times$ $10^{-5}$ to $5.4 \times 10^{-3} \mu \mathrm{g} \mathrm{m}^{-3}$, much lower than our findings (<LOD-0.19 $\left.\mu \mathrm{g} \mathrm{m}^{-3}\right)$. In our study, we collected air samples on the day of pesticide application in the fields, whereas the Washington study could not confirm that the target pesticides had been sprayed in the nearby tree fruit field during the sampling period (Gibbs et al., 2017).

\subsubsection{Take-home pathway}

As there was little variance in household proximity to the sprayed fields in our study, we assert that the significantly higher pesticide levels in applicator versus non-applicator households can be ascribed to applicators bringing the pesticide residues home with them on the clothes that they had worn during spraying activities. On the days of indoor air sample collection, all target pesticides had been sprayed in the morning by applicators who participated in our previous investigation into applicators' pesticide inhalation exposures. After spraying activities were concluded for the day, the applicators were followed to their homes for the collection of indoor air samples. The high concentrations of pesticide residues detected in their households provide evidence of potential secondary exposure to pesticides among family members. Notably, pesticide levels were significantly higher in applicator households than in non-applicator households for ametryn ( 0.75 vs. $0.19 \mu \mathrm{g} \mathrm{m}^{-3}$ ) and pendimethalin ( 0.57 vs. $0.04 \mu \mathrm{g} \mathrm{m}^{-3}$ ) (Table 1). For atrazine, the difference in concentrations between applicator and non-applicator households was marginally significant. At $25^{\circ} \mathrm{C}$, the vapor pressures of our target compounds are $9.40 \times 10^{-6} \mathrm{mmHg}$ for pendimethalin, $2.74 \times 10^{-6} \mathrm{mmHg}$ for ametryn, $2.89 \times 10^{-7} \mathrm{mmHg}$ for atrazine and $1.39 \times 10^{-7}$ $\mathrm{mmHg}$ for 2,4-D (HSDB, 2020). Thus, it would be expected that the highly volatile pesticides (ametryn and pendimethalin) would easily vaporize and travel through air onto the skin, clothes and shoes of the applicators, and also enter the nearby households via drift conditions. This would explain why our results show that ametryn and pendimethalin have the highest levels detected in both sets of households. It was difficult to estimate the amount of each pesticide sprayed in the fields on each spraying day. Moreover, it is likely that unequal amounts of each pesticide were sprayed in the sugarcane fields. Thus, the different airborne concentrations of the pesticides detected in our samples reflect the amounts of pesticides sprayed. The results in this paper are consistent with the levels of pesticide residues in applicators' personal air samples in our previous paper, which reported the highest detection rates and mean concentrations for ametryn and pendimethalin and the lowest detection rate and concentrations for 2,4-D amongst all four pesticides studied (Msibi et al., 2021). Since 2,4-D was only detected in $33.3 \%$ of each type of household, 2,4-D was not detected frequently enough ( $>50 \%$ ) to allow for meaningful analysis of statistical significance of the difference between households. Our data in Table 1 suggest that the take-home pathway is the most influential source of indoor agricultural pesticides and demonstrate much higher indoor concentrations of ametryn and pendimethalin in applicator households compared with those in non-applicator households.

Our observations are consistent with previous studies that illustrate significant increases in residential exposure to agricultural pesticides via the take-home pathway (Curl et al., 2002; Hogenkamp et al., 2004; Coronado et al., 2006; Thompson et al., 2014; Tamaro et al., 2018). For example, Golla et al. (2012) found that workers on farms using a commercial pesticide applicator to spray atrazine had lower levels of the pesticide inside their homes than farmers who applied the pesticide themselves. In a study from lowa in the USA, concentrations of several pesticides were more than 4-fold higher in homes of agricultural workers compared with homes without agricultural workers (Ward et al., 2006). Other researchers have reported finding pesticides solely 
used in agriculture, such as atrazine and metolachlor, only in households of applicators spraying these particular pesticides (Curwin et al., 2005; Arcury et al., 2007; Hyland and Laribi, 2017). In addition, biomonitoring studies have shown that children in households of pesticide applicators exhibit statistically higher concentrations of metabolites than children from households without farm workers (Fenske et al., 2000; Lu et al., 2000; Lambert et al., 2005; Coronado et al., 2006). In a study that investigated concentrations of organophosphate (OP) pesticide residue in house dust from an American agricultural community, Lu et al. (2000) reported that levels of the pesticide metabolites in the urine of farmworkers' children were significantly higher than levels in the urine of non-farmworkers' children. They also found a marginally significant association between house dust concentrations and urinary metabolite concentrations of OP pesticides in farmworker families (Lu et al., 2000). In another USA study, Lozier et al. (2012) reported lower levels of atrazine inside homes where farmworkers removed their shoes before entering the home compared with homes where shoes were worn inside. Conversely, other studies have shown no evidence of pesticide exposure via the take-home pathway (Thompson et al., 2008; Coronado et al., 2012; Salvatore et al., 2015; González-Alzaga et al., 2018).

Most studies investigating exposure to agricultural pesticides via the take-home pathway have broadly focused on farmworker households. For example, one study (Lu et al., 2004) conducted in Washington, USA, focused on farmworker households, whilst our study specifically focused on applicator households. The study by Lu et al. (2004) investigated the presence of five OP pesticides in agricultural homes, which were defined as having at least one adult who worked in an agriculture-related job. The study reported mean indoor air concentrations ranging from $2 \times 10^{-3}$ to $4 \times 10^{-3} \mu \mathrm{g} \mathrm{m}^{-3}$ (Lu et al., 2004), which are much lower in comparison with our findings, in which indoor concentrations from applicator households ranged from $<$ LOD to $0.75 \mu \mathrm{g} \mathrm{m}^{-3}$. In addition, they found pesticide residues in house dust and children's hands and toys in agricultural homes, providing more evidence of household contamination via the take-home pathway (Lu et al., 2004). Pesticide applicators using spraying equipment in the fields are more exposed to pesticides than other farmworkers such as harvesters and machine operators; therefore, it would be expected that applicators would transfer higher levels of pesticide residues into their homes.

\subsection{Health Risk Assessment}

After completing the probabilistic risk assessment, we obtained $\mathrm{HQ}_{i}$ distributions representing the non-cancer risk due to inhalation exposures for each of the four pesticides in all age groups (Table 3). In a comparison of both sets of data, household residents were most likely to be exposed to ametryn and least of all to 2,4-D. The risk of exposure was up to 4 times higher in applicator households than in non-applicator households. Children aged 1-3 years were consistently at the highest risk of exposure to all target compounds, with mean $\mathrm{HQ}$ values for ametryn, atrazine, pendimethalin and 2,4-D in applicator households of $0.358,0.033,0.053$ and $5.4 \times 10^{-4}$, respectively. In applicator households, $\mathrm{HQ}$ values at the $95^{\text {th }}$ percentile ( $\mathrm{HQ}_{95}$ ) for children aged $0.5-0.9$ and 1-3 years exceeded 1 for ametryn (i.e., 1.001 and 1.101, respectively) (see Table 3 and Fig. S2). This finding indicates a significant health risk resulting from ametryn inhalation exposure among children in applicator households. However, this risk may be compounded by various other factors, including exposures through dermal absorption and ingestion of pesticide residues in the environment. Coscolla et al. (2017) investigated pesticide levels in outdoor ambient air in a rural French community and reported a maximum $\mathrm{HQ}$ value for pendimethalin of $9.29 \times 10^{-5}$ for infants ( 6 months-1.5 years). In comparison, our data revealed an $\mathrm{HQ}_{95}$ value of 0.01 for the risk of exposure to pendimethalin among infants aged 0.5-0.9 years in non-applicator households. Recent studies describing risk assessments of inhalation exposure to pesticides have reported higher HQ values for infants and children compared with values among adults (Li et al., 2014; Yusà et al., 2014; Coscolla et al., 2017). Notwithstanding, all of those reported HQ values were less than 1, which is considered an acceptable risk.

At the $95^{\text {th }}$ percentile, the cumulative risk of exposure to all target compounds was $>1$ in applicator households for children aged 0-3 years, which is concerning, as such a risk is considered unacceptable (Fig. 3). In contrast, in the non-applicator households, the mean and $95^{\text {th }}$ percentile cumulative risk was acceptable at $<1$ for all age groups. It is worth noting that our results represent the high-end risk of exposure; families in the applicator households may not be 
Table 3. $\mathrm{HQ}$ values due to indoor exposures to the target compounds.

\begin{tabular}{|c|c|c|c|c|c|c|c|c|}
\hline \multirow{2}{*}{$\begin{array}{l}\text { Age group } \\
\text { (years) }\end{array}$} & \multirow{2}{*}{$\begin{array}{l}\text { Inhalation rate } \\
\left(\mathrm{m}^{3} \text { day }^{-1}\right)\end{array}$} & \multirow{2}{*}{$\begin{array}{l}\text { Body weight } \\
\text { (kg) }\end{array}$} & \multicolumn{3}{|c|}{ Applicator households } & \multicolumn{3}{|c|}{ Non-applicator households } \\
\hline & & & Mean & $95^{\text {th }}$ percentile & SD & Mean & $95^{\text {th }}$ percentile & SD \\
\hline \multicolumn{9}{|l|}{ Ametryn } \\
\hline$<0.5$ & 4.1 & 7.4 & 0.308 & 0.944 & 0.290 & 0.083 & 0.252 & 0.078 \\
\hline $0.5-0.9$ & 5.4 & 9.2 & 0.325 & 1.001 & 0.308 & 0.087 & 0.267 & 0.082 \\
\hline $1-3$ & 8.9 & 13.8 & 0.358 & 1.101 & 0.338 & 0.096 & 0.294 & 0.090 \\
\hline $4-2$ & 12 & 31.8 & 0.209 & 0.642 & 0.198 & 0.056 & 0.172 & 0.053 \\
\hline $13-18$ & 15.2 & 56.8 & 0.149 & 0.456 & 0.140 & 0.040 & 0.122 & 0.037 \\
\hline $19-65$ & 16.3 & 68.1 & 0.133 & 0.409 & 0.125 & 0.036 & 0.108 & 0.033 \\
\hline$>65$ & 14.2 & 68.1 & 0.116 & 0.355 & 0.109 & 0.031 & 0.095 & 0.030 \\
\hline \multicolumn{9}{|l|}{ Atrazine } \\
\hline$<0.5$ & 4.1 & 7.4 & 0.029 & 0.111 & 0.040 & 0.003 & 0.008 & 0.002 \\
\hline $0.5-0.9$ & 5.4 & 9.2 & 0.030 & 0.117 & 0.042 & 0.003 & 0.008 & 0.002 \\
\hline $1-3$ & 8.9 & 13.8 & 0.033 & 0.128 & 0.046 & 0.003 & 0.009 & 0.003 \\
\hline $4-12$ & 12 & 31.8 & 0.020 & 0.075 & 0.027 & 0.002 & 0.005 & 0.002 \\
\hline $13-18$ & 15.2 & 56.8 & 0.014 & 0.053 & 0.019 & 0.001 & 0.004 & 0.001 \\
\hline $19-65$ & 16.3 & 68.1 & 0.012 & 0.047 & 0.017 & 0.001 & 0.003 & 0.001 \\
\hline$>65$ & 14.2 & 68.1 & 0.011 & 0.041 & 0.015 & 0.001 & 0.003 & 0.001 \\
\hline \multicolumn{9}{|c|}{ Pendimethalin } \\
\hline$<0.5$ & 4.1 & 7.4 & 0.045 & 0.160 & 0.053 & 0.003 & 0.008 & 0.002 \\
\hline $0.5-0.9$ & 5.4 & 9.2 & 0.048 & 0.170 & 0.056 & 0.003 & 0.008 & 0.002 \\
\hline $1-3$ & 8.9 & 13.8 & 0.053 & 0.186 & 0.061 & 0.003 & 0.009 & 0.003 \\
\hline $4-12$ & 12 & 31.8 & 0.031 & 0.109 & 0.036 & 0.002 & 0.005 & 0.002 \\
\hline $13-18$ & 15.2 & 56.8 & 0.022 & 0.077 & 0.025 & 0.001 & 0.004 & 0.001 \\
\hline $19-65$ & 16.3 & 68.1 & 0.020 & 0.069 & 0.023 & 0.001 & 0.003 & 0.001 \\
\hline$>65$ & 14.2 & 68.1 & 0.017 & 0.060 & 0.020 & 0.001 & 0.003 & 0.001 \\
\hline \multicolumn{9}{|l|}{$2,4-D$} \\
\hline$<0.5$ & 4.1 & 7.4 & $5.0 \times 10^{-4}$ & 0.002 & $6.2 \times 10^{-4}$ & $3.9 \times 10^{-4}$ & 0.001 & $3.7 \times 10^{-4}$ \\
\hline $0.5-0.9$ & 5.4 & 9.2 & $5.2 \times 10^{-4}$ & 0.002 & $6.6 \times 10^{-4}$ & $4.1 \times 10^{-4}$ & 0.001 & $4.0 \times 10^{-4}$ \\
\hline $1-3$ & 8.9 & 13.8 & $5.8 \times 10^{-4}$ & 0.002 & $7.3 \times 10^{-4}$ & $4.6 \times 10^{-4}$ & 0.001 & $4.4 \times 10^{-4}$ \\
\hline $4-12$ & 12 & 31.8 & $3.4 \times 10^{-4}$ & 0.001 & $4.2 \times 10^{-4}$ & $2.7 \times 10^{-4}$ & 0.001 & $2.6 \times 10^{-4}$ \\
\hline $13-18$ & 15.2 & 56.8 & $2.4 \times 10^{-4}$ & 0.001 & $3.0 \times 10^{-4}$ & $1.9 \times 10^{-4}$ & 0.001 & $1.8 \times 10^{-4}$ \\
\hline $19-65$ & 16.3 & 68.1 & $2.1 \times 10^{-4}$ & 0.001 & $2.7 \times 10^{-4}$ & $1.7 \times 10^{-4}$ & 0.001 & $1.6 \times 10^{-4}$ \\
\hline$>65$ & 14.2 & 68.1 & $1.9 \times 10^{-4}$ & 0.001 & $2.3 \times 10^{-4}$ & $1.5 \times 10^{-4}$ & 0.001 & $1.4 \times 10^{-4}$ \\
\hline
\end{tabular}

exposed to the high levels of the target pesticides reported in this study every day throughout the year. However, we highly recommend that after completing spraying activities, applicators should change and wash their personal protective equipment (PPE), shower, and wash all clothing worn while spraying, before they leave the workstation. Such measures will minimize the risk to households posed by take-home pesticides.

\subsection{Limitations of the Study}

This study describes finding high levels of agricultural pesticides in households on the days of spraying in nearby farms; the main contributors to these high levels were take-home and spray drift pathways. We only assessed residential inhalation exposure to four pesticides, so did not account for other routes of exposure, such as dermal and ingestion routes, despite being aware that the household members are also exposed to pesticides through dust, water, soil and food. Quantifying these multiple co-exposures would more comprehensively cover levels of nonoccupational exposure in the households. In addition, our analysis may have underestimated the cumulative risk of inhalation exposure to pesticides, as residents are exposed to other pesticides used in the study area. Studies investigating the presence of pesticides in house dust have detected pesticide residues in carpet dust and on children's hands and their toys (Lu et al., 2000; Curl et al., 2002; Lu et al., 2004). Young children are inclined to touch the floor and other surfaces 


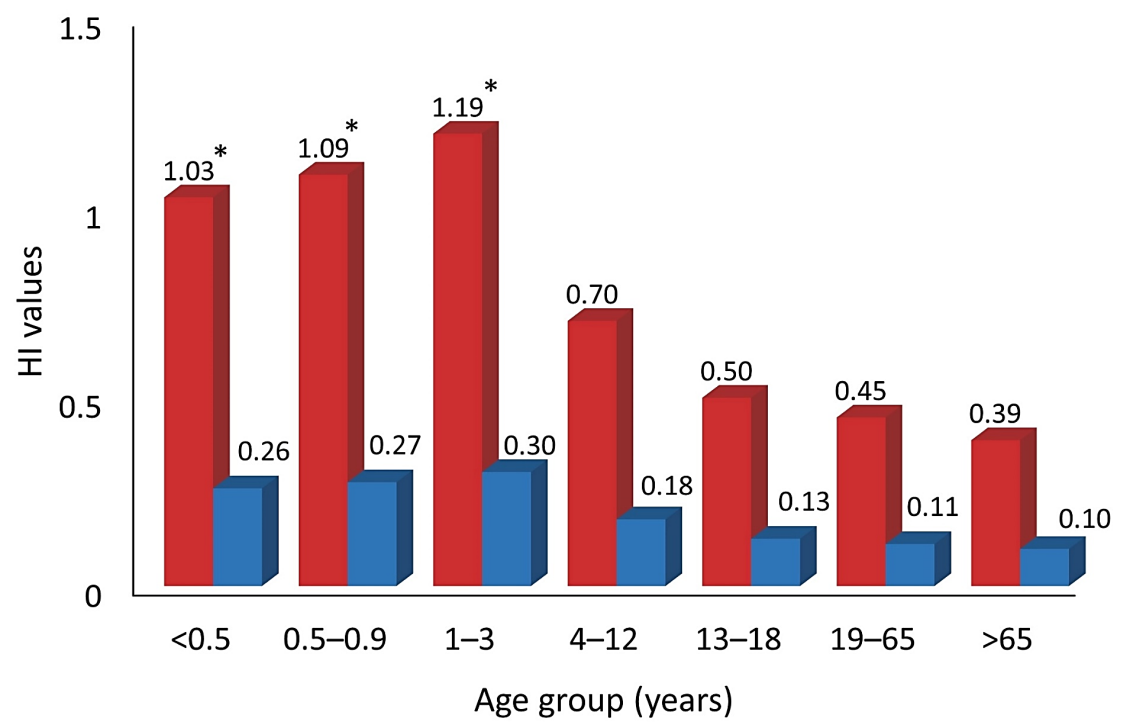

Fig. 3. $\mathrm{HI}$ values at $95^{\text {th }}$ percentile showing the cumulative risk for each age group for all four target compounds. * Hazard index $>1$.

as they crawl and play with their toys, so are very likely to ingest dust through hand-to-mouth contact (Lu et al., 2004). As our study did not investigate pesticide levels in house dust, we may have underestimated the level of exposure and the resulting cumulative health risk. Longitudinal monitoring of the study area would provide greater understanding of the complexity and changes in pesticide levels through different seasons and pathways. Furthermore, biomonitoring data would have been useful, as biomarkers represent the summation of exposure and could provide an estimate of the internal doses for family members and the associated adverse health effects.

\section{CONCLUSIONS AND RECOMMENDATIONS}

Our findings, which detail the risks posed by indoor residential inhalation exposure to pesticides in Swazi agricultural communities, may serve as a basis for future regulatory and behavioral interventions in African countries. We measured significantly higher levels of agricultural pesticides in the applicators' homes than in the non-applicators' homes, with young children in applicators' households being the most vulnerable to exposure. As the distances from all of the residences to the adjacent sugarcane fields were similar, the concentrations we found may have been influenced by pesticide residues transported home by the applicators. We therefore urge farms and pesticide applicators to implement more stringent measures for mitigating exposure via the take-home pathway. Our results and recommendations may be valid for other African nations where farmworker families typically reside near agricultural land. Comprehensively assessing this population's household exposure to pesticides, i.e., from all environmental media, warrants further research. Moreover, epidemiological studies must be conducted in such communities.

\section{DISCLAIMER}

The authors declare no conflicts of interest.

\section{SUPPLEMENTARY MATERIAL}

Supplementary material for this article can be found in the online version at https://doi. org/10.4209/aaqr.210062 


\section{ACKNOWLEDGMENTS}

This work was financially supported by the Carlo Urbani Taiwan Association and the Ministry of Foreign Affairs (MOFA) in Taiwan. We would like to thank Khulekani Msweli, the managers of Vuvulane farm and members of the farm's households, for their assistance during sample collection. We acknowledge the enduring support and assistance we received from the laboratory in Chang Jung Christian University (Tainan, Taiwan) during chemical analysis. We also thank Iona J. MacDonald from China Medical University, Taichung, Taiwan, for her editing of the manuscript.

\section{REFERENCES}

Alavanja, M.C., Sandler, D.P., McDonnell, C.J., Lynch, C.F., Pennybacker, M., Zahm, S.H., Mage, D.T., Steen, W.C., Wintersteen, W., Blair, A. (1999). Characteristics of pesticide use in a pesticide applicator cohort: The Agricultural Health Study. Environ. Res. 80, 172-179. https://doi.org/10.1006/enrs.1998.3888

Arcury, T.A., Grzywacz, J.G., Barr, D.B., Tapia, J., Chen, H., Quandt, S.A. (2007). Pesticide urinary metabolite levels of children in eastern North Carolina farmworker households. Environ. Health Perspect. 115, 1254-1260. https://doi.org/doi:10.1289/ehp.9975

Arinaitwe, K., Kiremire, B.T., Muir, D.C.G., Fellin, P., Li, H., Teixeira, C., Mubiru, D.N. (2016). Legacy and currently used pesticides in the atmospheric environment of Lake Victoria, East Africa. Sci. Total Environ. 543, 9-18. https://doi.org/10.1016/j.scitotenv.2015.10.146

Barnhoorn, I.E.J., Bornman, M.S., van Rensburg, C.J., Bouwman, H. (2009). DDT residues in water, sediment, domestic and indigenous biota from a currently DDT-sprayed area. Chemosphere 77, 1236-1241. https://doi.org/10.1016/j.chemosphere.2009.08.045

Bennett, B., Workman, T., Smith, M.N., Griffith, W.C., Thompson, B., Faustman, E.M. (2019). Longitudinal, seasonal, and occupational trends of multiple pesticides in house Dust. Environ. Health Perspect. 127, 17003. https://doi.org/10.1289/ehp3644

Berglund, B., Brunekreef, B., Knöppe, H., Lindvall, T., Maroni, M., Mølhave, L., Skov, P. (1992). Effects of indoor air pollution on human health. Indoor Air 2, 2-25. https://doi.org/10.1111/j.1 600-0668.1992.02-21.x

Bradman, A., Castorina, R., Boyd Barr, D., Chevrier, J., Harnly, M.E., Eisen, E.A., McKone, T.E., Harley, K., Holland, N., Eskenazi, B. (2011). Determinants of organophosphorus pesticide urinary metabolite levels in young children living in an agricultural community. Int. J. Environ. Res. Public Health 8, 1061-1083. https://doi.org/10.3390/ijerph8041061

Brouwer, M., Kromhout, H., Vermeulen, R., Duyzer, J., Kramer, H., Hazeu, G., de Snoo, G., Huss, A. (2018). Assessment of residential environmental exposure to pesticides from agricultural fields in the Netherlands. J. Exposure Sci. Environ. Epidemiol. 28, 173-181. https://doi.org/10.1 038/jes.2017.3

Campos, É., Freire, C. (2016). Exposure to non-persistent pesticides and thyroid function: A systematic review of epidemiological evidence. Int. J. Hyg. Environ. Health 219, 481-497. https://doi.org/10.1016/j.ijheh.2016.05.006

Carlsen, S.C., Spliid, N.H., Svensmark, B. (2006). Drift of 10 herbicides after tractor spray application. 2. Primary drift (droplet drift). Chemosphere 64, 778-786. https://doi.org/10.1016/j.chemosp here.2005.10.060

Chang, E.T., Adami, H.O., Bailey, W.H., Boffetta, P., Krieger, R.I., Moolgavkar, S.H., Mandel, J.S (2014). Validity of geographically modeled environmental exposure estimates. Crit. Rev. Toxicol. 44, 450-466. https://doi.org/10.3109/10408444.2014.902029

Cherry, N., Beach, J., Senthilselvan, A., Burstyn, I. (2018). Pesticide use and asthma in Alberta grain farmers. Int. J. Environ. Res. Public Health 15, 526. https://doi.org/10.3390/ijerph15030526

Chetty-Mhlanga, S., Fuhrimann, S., Basera, W., Eeftens, M., Röösli, M., Dalvie, M.A. (2021). Association of activities related to pesticide exposure on headache severity and neurodevelopment of school-children in the rural agricultural farmlands of the Western Cape of South Africa. Environ. Int. 146, 106237. https://doi.org/10.1016/j.envint.2020.106237

Chevrier, C., Serrano, T., Lecerf, R., Limon, G., Petit, C., Monfort, C., Hubert-Moy, L., Durand, G., Cordier, S. (2014). Environmental determinants of the urinary concentrations of herbicides 
during pregnancy: The PELAGIE mother-child cohort (France). Environ. Int. 63, 11-18. https://doi.org/10.1016/j.envint.2013.10.010

Coker, E., Chevrier, J., Rauch, S., Bradman, A., Obida, M., Crause, M., Bornman, R., Eskenazi, B. (2018). Association between prenatal exposure to multiple insecticides and child body weight and body composition in the VHEMBE South African birth cohort. Environ. Int. 113, 122-132. https://doi.org/10.1016/j.envint.2018.01.016

Coronado, G.D., Vigoren, E.M., Thompson, B., Griffith, W.C., Faustman, E.M. (2006). Organophosphate pesticide exposure and work in pome fruit: Evidence for the take-home pesticide pathway. Environ. Health Perspect. 114, 999-1006. https://doi.org/10.1289/ehp.8620

Coronado, G.D., Holte, S., Vigoren, E., Griffith, W.C., Barr, D.B., Faustman, E., Thompson, B. (2011a). Organophosphate pesticide exposure and residential proximity to nearby fields: Evidence for the drift pathway. J. Occup. Environ. Med. 53, 884-891. https://doi.org/10.1097/ JOM.0b013e318222f03a

Coronado, G.D., Livaudais, J., Hanisch, R., Tekeste, T. (2011b). Take-Home Route of Pesticide Exposure, in: Nriagu, J.O. (Ed.), Encyclopedia of Environmental Health, Elsevier, Burlington, pp. 312-324. https://doi.org/10.1016/B978-0-444-52272-6.00641-3

Coronado, G.D., Holte, S.E., Vigoren, E.M., Griffith, W.C., Barr, D.B., Faustman, E.M., Thompson, B. (2012). Do workplace and home protective practices protect farm workers? Findings from the "For Healthy Kids" study. J. Occup. Environ. Med. 54, 1163-1169. https://doi.org/10.1097/ JOM.0b013e31825902f5

Coscolla, C., Lopez, A., Yahyaoui, A., Colin, P., Robin, C., Poinsignon, Q., Yusa, V. (2017). Human exposure and risk assessment to airborne pesticides in a rural French community. Sci. Total Environ. 584-585, 856-868. https://doi.org/10.1016/j.scitotenv.2017.01.132

Curl, C.L., Fenske, R.A., Kissel, J.C., Shirai, J.H., Moate, T.F., Griffith, W., Coronado, G., Thompson, B. (2002). Evaluation of take-home organophosphorus pesticide exposure among agricultural workers and their children. Environ. Health Perspect. 110, A787-792. https://doi.org/10.1289/ ehp.021100787

Curwin, B.D., Hein, M.J., Sanderson, W.T., Nishioka, M.G., Reynolds, S.J., Ward, E.M., Alavanja, M.C. (2005). Pesticide contamination inside farm and nonfarm homes. J. Occup. Environ. Hyg. 2, 357-367. https://doi.org/10.1080/15459620591001606

da Silva, M., Stadlinger, N., Mmochi, A.J., Stålsby Lundborg, C., Marrone, G. (2016). Pesticide use and self-reported health symptoms among rice farmers in Zanzibar. J. Agromed. 21, 335-344 https://doi.org/10.1080/1059924x.2016.1211572

Dalvie, M.A., Sosan, M.B., Africa, A., Cairncross, E., London, L. (2014). Environmental monitoring of pesticide residues from farms at a neighbouring primary and pre-school in the Western Cape in South Africa. Sci. Total Environ. 466-467, 1078-1084. https://doi.org/10.1016/j.scitotenv.2 013.07.099

Debela, S.A., Wu, J., Chen, X., Zhang, Y. (2019). Stock status, urban public perception, and health risk assessment of obsolete pesticide in Northern Ethiopia. Environ. Sci. Pollut. Res. 27, 2583725847. https://doi.org/10.1007/s11356-019-05694-x

Dereumeaux, C., Fillol, C., Quenel, P., Denys, S. (2020). Pesticide exposures for residents living close to agricultural lands: A review. Environ. Int. 134, 105210. https://doi.org/10.1016/j.envi nt.2019.105210

El-Gamal, Y.M., Hossny, E.M., El-Sayed, Z.A., Reda, S.M. (2017). Allergy and immunology in Africa: Challenges and unmet needs. J. Allergy Clin. Immunol. 140, 1240-1243. https://doi.org/10.10 16/j.jaci.2017.09.004

El-Zaemey, S., Heyworth, J., Fritschi, L. (2013). Noticing pesticide spray drift from agricultural pesticide application areas and breast cancer: A case-control study. Aust. N. Z. J. Public Health 37, 547-555. https://doi.org/10.1111/1753-6405.12111

Eswatini Government (2014). WHO STEPS: Noncommunicable Disease Risk Factor Surveillance Report. World Health Organization. https://cdn.who.int/media/docs/default-source/ncds/ncdsurveillance/data-reporting/eswatini/steps/swaziland-2014-steps-report.pdf?sfvrsn=d33014 8c_2\&download=true

European Food Safety Authority (EFSA) (2014). Guidance on the assessment of exposure of operators, workers, residents and bystanders in risk assessment for plant protection products. EFSA Journal 12, 3874. https://doi.org/10.2903/j.efsa.2014.3874 
Farr, S.L., Cooper, G.S., Cai, J., Savitz, D.A., Sandler, D.P. (2004). Pesticide use and menstrual cycle characteristics among premenopausal women in the Agricultural Health Study. Am. J. Epidemiol. 160, 1194-1204. https://doi.org/10.1093/aje/kwi006

Fenske, R.A., Kissel, J.C., Lu, C., Kalman, D.A., Simcox, N.J., Allen, E.H., Keifer, M.C. (2000). Biologically based pesticide dose estimates for children in an agricultural community. Environ. Health Perspect. 108, 515-520. https://doi.org/10.1289/ehp.00108515

Fenske, R.A., Lu, C., Barr, D., Needham, L. (2002). Children's exposure to chlorpyrifos and parathion in an agricultural community in central Washington State. Environ. Health Perspect. 110, 549-553. https://doi.org/10.1289/ehp.02110549

Fuhrimann, S., Klánová, J., Přibylová, P., Kohoutek, J., Dalvie, M.A., Röösli, M., Degrendele, C. (2020). Qualitative assessment of 27 current-use pesticides in air at 20 sampling sites across Africa. Chemosphere 258, 127333. https://doi.org/10.1016/j.chemosphere.2020.127333

Gaspar, F.W., Chevrier, J., Bornman, R., Crause, M., Obida, M., Barr, D.B., Bradman, A., Bouwman, H., Eskenazi, B. (2015). Undisturbed dust as a metric of long-term indoor insecticide exposure: Residential DDT contamination from indoor residual spraying and its association with serum levels in the VHEMBE cohort. Environ. Int. 85, 163-167. https://doi.org/10.1016/j.envint.2015. 09.014

Gibbs, J.L., Yost, M.G., Negrete, M., Fenske, R.A. (2017). Passive sampling for indoor and outdoor exposures to chlorpyrifos, azinphos-methyl, and oxygen analogs in a rural agricultural community. Environ. Health Perspect. 125, 333-341. https://doi.org/10.1289/ehp425

Ginsberg, G., Hattis, D., Sonawane, B. (2004). Incorporating pharmacokinetic differences between children and adults in assessing children's risks to environmental toxicants. Toxicol. Appl. Pharmacol. 198, 164-183. https://doi.org/10.1016/j.taap.2003.10.010

Golla, V., Curwin, B., Sanderson, W., Nishioka, M. (2012). Pesticide concentrations in vacuum dust from farm homes: Variation between planting and nonplanting seasons. Int. Sch. Res. Notices 2012, 539397. https://doi.org/10.5402/2012/539397

González-Alzaga, B., Lacasaña, M., Hernández, A.F., Arrebola, J.P., López-Flores, I., ArtachoCordón, F., Bonde, J.P., Olea, N., Aguilar-Garduño, C. (2018). Serum concentrations of organochlorine compounds and predictors of exposure in children living in agricultural communities from South-Eastern Spain. Environ. Pollut. 237, 685-694. https://doi.org/10.101 6/j.envpol.2017.10.109

Grandjean, P., Landrigan, P.J. (2006). Developmental neurotoxicity of industrial chemicals. Lancet 368, 2167-2178. https://doi.org/10.1016/s0140-6736(06)69665-7

Hamsan, H., Ho, Y.B., Zaidon, S.Z., Hashim, Z., Saari, N., Karami, A. (2017). Occurrence of commonly used pesticides in personal air samples and their associated health risk among paddy farmers. Sci. Total Environ. 603-604, 381-389. https://doi.org/10.1016/j.scitotenv.2017.06.096

Hazardous Substances Data Bank (HSDB) (2020). HSDB. National Center for Biotechnology Information (NCBI), National Library of Medicine.

Health and Safety (HSE) (2015). Pesticides in air and on surfaces. MDHS94/2. https://www. hse.gov.uk/pubns/mdhs/pdfs/mdhs94-2.pdf

Hlongwana, K.W., Mavundza, E.J., Mohapi, E.P., Kruger, P., Urbach, J., Mukaratirwa, S., Maharaj, R. (2013). Vector-control personnel's knowledge, perceptions and practices towards insecticides used for indoor residual spraying in Limpopo Province, South Africa. Parasites Vectors 6, 118. https://doi.org/10.1186/1756-3305-6-118

Ho, Y.B., Zakaria, M.P., Latif, P.A., Saari, N. (2012). Simultaneous determination of veterinary antibiotics and hormone in broiler manure, soil and manure compost by liquid chromatographytandem mass spectrometry. J. Chromatogr. A 1262, 160-168. https://doi.org/10.1016/j.chrom a.2012.09.024

Hogenkamp, A., Vaal, M., Heederik, D. (2004). Pesticide exposure in dwellings near bulb growing fields in The Netherlands: An explorative study. Ann. Agric. Environ. Med. 11, 149-153.

Hyland, C., Gunier, R.B., Metayer, C., Bates, M.N., Wesseling, C., Mora, A.M. (2018). Maternal residential pesticide use and risk of childhood leukemia in Costa Rica. Int. J. Cancer 143, 12951304. https://doi.org/10.1002/ijc.31522

Hyland, C., Laribi, O. (2017). Review of take-home pesticide exposure pathway in children living in agricultural areas. Environ. Res. 156, 559-570. https://doi.org/10.1016/j.envres.2017.04.017 Joubert, B.R., Mantooth, S.N., McAllister, K.A. (2019). Environmental health research in Africa: 
Important progress and promising opportunities. Front. Genet. 10, 1166. https://doi.org/10.3 389/fgene.2019.01166

Kawahara, J., Horikoshi, R., Yamaguchi, T., Kumagai, K., Yanagisawa, Y. (2005). Air pollution and young children's inhalation exposure to organophosphorus pesticide in an agricultural community in Japan. Environ. Int. 31, 1123-1132. https://doi.org/10.1016/j.envint.2005.04.001

Koch, D., Lu, C., Fisker-Andersen, J., Jolley, L., Fenske, R.A. (2002). Temporal association of children's pesticide exposure and agricultural spraying: Report of a longitudinal biological monitoring study. Environ. Health Perspect. 110, 829-833. https://doi.org/10.1289/ehp.0211 0829

Lambert, W.E., Lasarev, M., Muniz, J., Scherer, J., Rothlein, J., Santana, J., McCauley, L. (2005). Variation in organophosphate pesticide metabolites in urine of children living in agricultural communities. Environ. Health Perspect. 113, 504-508. https://doi.org/10.1289/ehp.6890

Landrigan, P.J., Goldman, L.R. (2011). Protecting children from pesticides and other toxic chemicals. J. Exposure Sci. Environ. Epidemiol. 21, 119-120. https://doi.org/10.1038/jes.2011.1

Larsen, A.E., Gaines, S.D., Deschênes, O. (2017). Agricultural pesticide use and adverse birth outcomes in the San Joaquin Valley of California. Nat. Commun. 8, 302. https://doi.org/10.10 38/s41467-017-00349-2

Li, H., Ma, H., Lydy, M.J., You, J. (2014). Occurrence, seasonal variation and inhalation exposure of atmospheric organophosphate and pyrethroid pesticides in an urban community in South China. Chemosphere 95, 363-369. https://doi.org/10.1016/j.chemosphere.2013.09.046

López-Gálvez, N., Wagoner, R., Quirós-Alcalá, L., Ornelas Van Horne, Y., Furlong, M., Avila, E., Beamer, P. (2019). Systematic literature review of the take-home route of pesticide exposure via biomonitoring and environmental monitoring. Int. J. Environ. Res. Public Health 16, 2177. https://doi.org/10.3390/ijerph16122177

Lozier, M.J., Curwin, B., Nishioka, M.G., Sanderson, W. (2012). Determinants of atrazine contamination in the homes of commercial pesticide applicators across time. J. Occup. Environ. Hyg. 9, 289-297. https://doi.org/10.1080/15459624.2012.668658

Lu, C., Fenske, R.A., Simcox, N.J., Kalman, D. (2000). Pesticide exposure of children in an agricultural community: Evidence of household proximity to farmland and take home exposure pathways. Environ. Res. 84, 290-302. https://doi.org/10.1006/enrs.2000.4076

Lu, C., Kedan, G., Fisker-Andersen, J., Kissel, J.C., Fenske, R.A. (2004). Multipathway organophosphorus pesticide exposures of preschool children living in agricultural and nonagricultural communities. Environ. Res. 96, 283-289. https://doi.org/10.1016/j.envres.2004.01.009

Ma, X., Buffler Patricia, A., Gunier Robert, B., Dahl, G., Smith Martyn, T., Reinier, K., Reynolds, P. (2002). Critical windows of exposure to household pesticides and risk of childhood leukemia. Environ. Health Perspect. 110, 955-960. https://doi.org/10.1289/ehp.02110955

Manyilizu, W.B., Mdegela, R.H., Kazwala, R., Nonga, H., Muller, M., Lie, E., Skjerve, E., Lyche, J.L. (2016). Association of long-term pesticide exposure and biologic parameters in female farm workers in Tanzania: A cross sectional study. Toxics 4, 25. https://doi.org/10.3390/toxics4040025

Menegaux, F., Baruchel, A., Bertrand, Y., Lescoeur, B., Leverger, G., Nelken, B., Sommelet, D., Hémon, D., Clavel, J. (2006). Household exposure to pesticides and risk of childhood acute leukaemia. Occup. Environ. Med. 63, 131. https://doi.org/10.1136/oem.2005.023036

Mostafalou, S., Abdollahi, M. (2017). Pesticides: An update of human exposure and toxicity. Arch. Toxicol. 91, 549-599. https://doi.org/10.1007/s00204-016-1849-x

Moussaoui, Y., Tuduri, L., Kerchich, Y., Meklati, B.Y., Eppe, G. (2012). Atmospheric concentrations of PCDD/Fs, dl-PCBs and some pesticides in northern Algeria using passive air sampling. Chemosphere 88, 270-277. https://doi.org/10.1016/j.chemosphere.2012.02.025

Msibi, S.S., Chen, C.Y., Chang, C.P., Chen, C.J., Chiang, S.Y., Wu, K.Y. (2021). High pesticide inhalation exposure from multiple spraying sources amongst applicators in Eswatini, Southern Africa. Pest Manage. Sci. https://doi.org/10.1002/ps.6459

Murray, J., Eskenazi, B., Bornman, R., Gaspar, F.W., Crause, M., Obida, M., Chevrier, J. (2018). Exposure to DDT and hypertensive disorders of pregnancy among South African women from an indoor residual spraying region: The VHEMBE study. Environ. Res. 162, 49-54. https://doi.org/10.1016/j.envres.2017.12.006

National Research Council (NRI) (1993). Pesticides in the Diets of Infants and Children. The National Academies Press, Washington, DC. https://doi.org/10.17226/2126 
National Research Council (NRI) (2000). Environmental and Exposure Pathways. in: Strategies to Protect the Health of Deployed U.S. Forces: Detecting, Characterizing, and Documenting Exposures. The National Academies Press, Washington, DC. pp. 68-85. https://doi.org/10.172 26/9767

Naudé, Y., Rohwer, E.R. (2012). Novel method for determining DDT in vapour and particulate phases within contaminated indoor air in a malaria area of South Africa. Anal. Chim. Acta 730, 112-119. https://doi.org/10.1016/j.aca.2012.02.054

Oesterlund, A.H., Thomsen, J.F., Sekimpi, D.K., Maziina, J., Racheal, A., Jørs, E. (2014). Pesticide knowledge, practice and attitude and how it affects the health of small-scale farmers in Uganda: A cross-sectional study. Afr. Health Sci. 14, 420-433. https://doi.org/10.4314/ahs.v14 i2.19

Özkara, A., Akyıl, D., Konuk, M. (2016). Pesticides, Environmental Pollution, and Health, Environmental Health Risk - Hazardous Factors to Living Species. IntechOpen. https://doi.org/ $10.5772 / 63094$

Quandt, S.A., Arcury, T.A., Rao, P., Snively, B.M., Camann, D.E., Doran, A.M., Yau, A.Y., Hoppin, J.A., Jackson, D.S. (2004). Agricultural and residential pesticides in wipe samples from farmworker family residences in North Carolina and Virginia. Environ. Health Perspect. 112, 382-387. https://doi.org/10.1289/ehp.6554

Rudant, J., Menegaux, F., Leverger, G., Baruchel, A., Nelken, B., Bertrand, Y., Patte, C., Pacquement, H., Vérité, C., Robert, A., Michel, G., Margueritte, G., Gandemer, V., Hémon, D., Clavel, J. (2007). Household exposure to pesticides and risk of childhood hematopoietic malignancies: The ESCALE study (SFCE). Environ. Health Perspect. 115, 1787-1793. https://doi.org/10.1289/ehp.10596

Salvatore, A.L., Castorina, R., Camacho, J., Morga, N., López, J., Nishioka, M., Barr, D.B., Eskenazi, B., Bradman, A. (2015). Home-based community health worker intervention to reduce pesticide exposures to farmworkers' children: A randomized-controlled trial. J. Exposure Sci. Environ. Epidemiol. 25, 608-615. https://doi.org/10.1038/jes.2015.39

Sankoh, A.I., Whittle, R., Semple, K.T., Jones, K.C., Sweetman, A.J. (2016). An assessment of the impacts of pesticide use on the environment and health of rice farmers in Sierra Leone. Environ. Int. 94, 458-466. https://doi.org/10.1016/j.envint.2016.05.034

Shelton, J.F., Geraghty, E.M., Tancredi, D.J., Delwiche, L.D., Schmidt, R.J., Ritz, B., Hansen, R.L., Hertz-Picciotto, I. (2014). Neurodevelopmental disorders and prenatal residential proximity to agricultural pesticides: The CHARGE study. Environ. Health Perspect. 122, 1103-1109. https://doi.org/doi:10.1289/ehp.1307044

Shunthirasingham, C., Mmereki, B.T., Masamba, W., Oyiliagu, C.E., Lei, Y.D., Wania, F. (2010a). Fate of pesticides in the arid subtropics, Botswana, Southern Africa. Environ. Sci. Technol. 44, 8082-8088. https://doi.org/10.1021/es1024788

Shunthirasingham, C., Oyiliagu, C.E., Cao, X., Gouin, T., Wania, F., Lee, S.C., Pozo, K., Harner, T., Muir, D.C. (2010b). Spatial and temporal pattern of pesticides in the global atmosphere. J. Environ. Monit. 12, 1650-1657. https://doi.org/10.1039/c0em00134a

Siebers, J., Binner, R., Wittich, K.P. (2003). Investigation on downwind short-range transport of pesticides after application in agricultural crops. Chemosphere 51, 397-407. https://doi.org/ 10.1016/s0045-6535(02)00820-2

Simcox, N.J., Fenske, R.A., Wolz, S.A., Lee, I.C., Kalman, D.A. (1995). Pesticides in household dust and soil: exposure pathways for children of agricultural families. Environ. Health Perspect. 103, 1126-1134. https://doi.org/10.1289/ehp.951031126

Suarez-Lopez, J.R., Butcher, C.R., Gahagan, S., Checkoway, H., Alexander, B.H., Al-Delaimy, W.K. (2018). Acetylcholinesterase activity and time after a peak pesticide-use period among Ecuadorian children. Int. Arch. Occup. Environ. Health 91, 175-184. https://doi.org/10.1007/s 00420-017-1265-4

Tamaro, C.M., Smith, M.N., Workman, T., Griffith, W.C., Thompson, B., Faustman, E.M. (2018). Characterization of organophosphate pesticides in urine and home environment dust in an agricultural community. Biomarkers 23, 174-187. https://doi.org/10.1080/1354750X.2017.13 95080

Taylor, M., Lyons, S.M., Davie-Martin, C.L., Geoghegan, T.S., Hageman, K.J. (2020). Understanding trends in pesticide volatilization from agricultural fields using the pesticide loss via volatilization 
model. Environ. Sci. Technol. 54, 2202-2209. https://doi.org/10.1021/acs.est.9b04762

Thompson, B., Coronado, G.D., Vigoren, E.M., Griffith, W.C., Fenske, R.A., Kissel, J.C., Shirai, J.H., Faustman, E.M. (2008). Para niños saludables: A community intervention trial to reduce organophosphate pesticide exposure in children of farmworkers. Environ. Health Perspect. 116, 687-694. https://doi.org/10.1289/ehp.10882

Thompson, B., Griffith, W.C., Barr, D.B., Coronado, G.D., Vigoren, E.M., Faustman, E.M. (2014). Variability in the take-home pathway: Farmworkers and non-farmworkers and their children. J. Exposure Sci. Environ. Epidemiol. 24, 522-531. https://doi.org/10.1038/jes.2014.12

United States Environmental Protection Agency (U.S. EPA) (1997). Exposure factors handbook (final report, 1997). United States Environmental Protection Agency.

United States Environmental Protection Agency (U.S. EPA) (1998). Human health risk assessment protocol: Chapter 7 risk and hazard characterization. United States Environmental Protection Agency.

United States Environmental Protection Agency (U.S. EPA) (1999). Compendium Method TO-10A: Determination Of Pesticides And Polychlorinated Biphenyls In Ambient Air Using Low Volume Polyurethane Foam (PUF) Sampling Followed By Gas Chromatographic/Multi-Detector Detection (GC/MD). United States Environmental Protection Agency.

United States Environmental Protection Agency (U.S. EPA) (2011). Exposure Factors Handbook 2011 Edition (Final Report). United States Environmental Protection Agency.

United States Environmental Protection Agency (U.S. EPA) (2018). Chemicals Evaluated for Carcinogenic Potential (Annual Cancer Report 2018). United States Environmental Protection Agency.

United States Environmental Protection Agency (U.S. EPA) (2020). Integrated Risk Information System (IRIS). https://cfpub.epa.gov/ncea/risk/recordisplay.cfm?deid=2776 (accessed March 2020).

Van Dyk, J.C., Bouwman, H., Barnhoorn, I.E., Bornman, M.S. (2010). DDT contamination from indoor residual spraying for malaria control. Sci. Total Environ. 408, 2745-2752. https://doi.org/10.1016/j.scitotenv.2010.03.002

Van Maele-Fabry, G., Gamet-Payrastre, L., Lison, D. (2019). Household exposure to pesticides and risk of leukemia in children and adolescents: Updated systematic review and meta-analysis. Int. J. Hyg. Environ. Health 222, 49-67. https://doi.org/10.1016/j.ijheh.2018.08.004

Ward, M.H., Lubin, J., Giglierano, J., Colt, J.S., Wolter, C., Bekiroglu, N., Camann, D., Hartge, P., Nuckols, J.R. (2006). Proximity to crops and residential exposure to agricultural herbicides in lowa. Environ. Health Perspect. 114, 893-897. https://doi.org/doi:10.1289/ehp.8770

Weppner, S., Elgethun, K., Lu, C., Hebert, V., Yost, M.G., Fenske, R.A. (2006). The Washington aerial spray drift study: Children's exposure to methamidophos in an agricultural community following fixed-wing aircraft applications. J. Exposure Sci. Environ. Epidemiol. 16, 387-396. https://doi.org/10.1038/sj.jea.7500461

Whitmore, R.W., Immerman, F.W., Camann, D.E., Bond, A.E., Lewis, R.G., Schaum, J.L. (1994). Non-occupational exposures to pesticides for residents of two U.S. cities. Arch. Environ. Contam. Toxicol. 26, 47-59. https://doi.org/10.1007/BF00212793

Windham, G., Mitchell, P., Petreas, M., Lee, D., Lasley, B. (2002). Exposure of DDT and metabolites in relation to menstrual cycle length among Laotian immigrants. Epidemiology 13, S198-S198.

Wolters, A., Linnemann, V., van de Zande, J.C., Vereecken, H. (2008). Field experiment on spray drift: Deposition and airborne drift during application to a winter wheat crop. Sci. Total Environ. 405, 269-277. https://doi.org/10.1016/j.scitotenv.2008.06.060

World Health Organization (WHO) (2016). World Malaria Report 2016. World Health Organization, Geneva.

Wu, C., Feng, C., Qi, X., Wang, G., Zheng, M., Chang, X., Zhou, Z. (2013). Urinary metabolite levels of pyrethroid insecticides in infants living in an agricultural area of the Province of Jiangsu in China. Chemosphere 90, 2705-2713. https://doi.org/10.1016/j.chemosphere.2012.11.050

Yusà, V., Coscollà, C., Millet, M. (2014). New screening approach for risk assessment of pesticides in ambient air. Atmos. Environ. 96, 322-330. https://doi.org/10.1016/j.atmosenv.2014.07.047 